\title{
THE CYTOKERATIN 18, ADIPONECTIN AND LEPTIN LEVELS IN PATIENTS WITH NON-ALCOHOLIC STEATOHEPATITIS AND CORONARY HEART DISEASE
}

\author{
Oksana S. KHUKHLINA ${ }^{1}$, Olha B. KUZMINSKA ${ }^{1 凶}$, Alona A. ANTONIV ${ }^{1}$, Tamara H. KOPCHUK ${ }^{2}$, \\ Svitlana P. MELNYCHUK ${ }^{2}$
}

${ }^{1}$ Department of Internal Medicine, Clinical Pharmacology and Occupational Diseases, Higher State Educational Institution of Ukraine „Bukovinian State Medical University“, Chernivtsi, Ukraine

${ }^{2}$ Department of Pharmacology, Higher State Educational Institution of Ukraine „Bukovinian State Medical University“, Chernivtsi, Ukraine

Received 14 May 2019, Accepted 29 July 2019

https://doi.org/10.31688/ABMU.2019.54.3.09

\section{Abstract}

The aim of the study was to determine the level of cytokeratin 18, adiponectin and leptin in plasma of the patients with nonalcoholic steatohepatitis (NASH) and coronary heart disease (CHD) and their association with the degree of cytolysis, disorders of carbohydrate and lipid metabolism.

Materials and methods. We examined 60 patients with NASH, who were divided into 2 groups: group 1 - 30 patients with NASH on the background of obesity of 1st-2nd degree, group 2 - 30 patients with $\mathrm{NASH}$ and CHD (the 1st and 2nd functional classes of stable angina pectoris) and obesity of 1 st-2nd degree. The mean age of patients was $55.13 \pm 6.34$ years. The control group consisted of 20 practically healthy persons (PHP). Serum CK18, adiponectin and leptin levels were determined by the immunoassay analysis.

Results. Our research showed that NASH is closely associated with disorders of adipocytokine homeostasis. In patients with NASH, comorbid CHD, and obesity of 1st-2nd degree, there is an increase level of CK

\section{Résumé}

Le contenu de la cytokératine 18 , de l'adiponectine et de la leptine chez des patients atteints d'une stéatose hépatique non alcoolique chronique et cardiopathie ischémique

But: déterminer le niveau de cytokératine 18, d'adiponectine et de leptine dans le plasma des patients atteints de NASH et leur association avec le degré de cytolyse, la violation du métabolisme des glucides et des lipides lors de la comorbidité avec une cardiopathie ischémique.

Matériel et méthodes: Soixante patients atteints de NASH ont été examinés et divisés en 2 groupes : ler groupe - 30 patients atteints de NASH sur fond d'obésité degré I-II, Zème groupe - 30 patients atteints de NASH avec coronaropathie (angor stable II et II) et obésité I-II degré. L'âge moyen des patients était de $55,13 \pm 6,34$ ans. Le groupe témoin était composé de 20 personnes pratiquement en bonne santé. La détermination du taux de cytokératines 18 , d'adiponectine et 
18, proinflammatory adipokine leptin and a decrease in the level of adiponectin.

Conclusions. The significant increase of liver aminotransferases activity and the level of CK 18 in patients with NASH, their close positive correlation relationship suggest that the leading pathophysiological mechanism of progression of NAFLD is the necrosis and apoptosis of hepatocytes. The determination of serum fragments of CK 18 can be used as a non-invasive test for diagnosis of NASH and liver steatosis.

Keywords: non-alcoholic steatohepatitis, coronary heart disease, cytokeratin 18, adiponectin, leptin.

\section{List of abbreviations:}

NAFLD $=$ non-alcoholic fatty liver disease

CK $18=$ cytokeratin 18

$\mathrm{CHD}=$ coronary heart disease

$\mathrm{NASH}=$ non-alcoholic steatohepatitis

$\mathrm{PHP}=$ practically healthy persons

$\mathrm{LR}=$ leptin resistance

$\mathrm{LF}=$ liver fibrosis

BMI $=$ body mass index

ALT $=$ alanine aminotransferase

AST $=$ aspartate aminotransferase

GGTP = gamma-glutamyl transpeptidase

$\mathrm{TG}=$ triglyceride

\section{INTRODUCTION}

The high prevalence of non-alcoholic fatty liver disease (NAFLD) in the world requires the development of new non-invasive methods of diagnosis ${ }^{1-5}$. Although the disease is still histologically determined by means of a liver biopsy, this is not a practical tool for a mass screening ${ }^{6}$. One of the most informative markers of the inflammation and liver fibrosis is the presence of the cytokeratin 18 (CK 18). CK 18 is a fragment of intermediate phylums of cells cytoskeleton, which is cut by the effector caspase 3 because of the process of apoptosis of hepatocytes ${ }^{7-11}$. This peptide is detected in the blood even before the morphological signs of apoptosis occur. This allows to use CK-18 as a non-invasive biomarker of non-alcoholic steatohepatitis (NASH) $)^{1-3,8-11}$.

\section{THE AIM OF THE STUDY}

To determine the level of cytokeratin 18 , adiponectin and leptin in plasma of patients with NASH and coronary heart disease (CHD) and their association with the degree of cytolysis, disorders of carbohydrate and lipid metabolism. de leptine dans le sérum sanguin a été réalisée par la méthode d'analyse immunologique.

Résultats : Notre étude a montré que la stéatose hépatique non-alcoolique est étroitement liée à l'homéostasie de l'adipocytokine. Pour les patients atteints de NASH pour comorbidité avec coronaropathie et obésité, le degré I-II est caractérisé par une augmentation des taux sanguins de CC-18, de leptine adipocytaire pro-inflammatoire et de réduction des taux d'adiponectine.

Conclusions: Laugmentation significative de l'activité aminotransférase dans le foie et du niveau du fragment CC-18 à la NASH, ainsi que leur étroite corrélation positive, confirment que le principal mécanisme physiopathologique de progression du NSChP est la nécrose et l'apoptose des hépatocytes, et la détermination de la fragmentation sérique du CK-18 peut être utilisée comme test non invasif pour le diagnostic de la NASH et de la stéatose du foie.

Mots-clés: stéatose hépatique non-alcoolique, cardiopathie ischémique, cytokératine 18 , adiponectine, leptine.

\section{Materials AND MEthods}

We examined 60 patients with NASH (31 men and 29 women), hospitalized between January 2016 to December 2018 in the Gastroenterology Department of the Regional Communal Institution „Emergency Hospital“, Chernivtsi, Ukraine. All patients were divided into 2 groups: group 1 - 30 patients with $\mathrm{NASH}$ on the background of obesity of $1^{\text {st }}-2^{\text {nd }}$ degree, group 2 - 30 patients with NASH and comorbid CHD ( I and II functional classes of stable angina pectoris) and obesity of $1^{\text {st }}-2^{\text {nd }}$ degree. These groups of patients were randomized according to age, sex, degree of obesity. The mean age of patients was $55.13 \pm 6.34$ years. The control group consisted of 20 practically healthy persons (PHP).

The study was conducted after the approval of the Ethics Committee of the Higher State Educational Institution of Ukraine „Bukovinian State Medical University", Ukraine. All patients signed the informed consent.

The diagnosis of NASH was established according to the recommendations of the European Association for the Study of Liver (EASL), the European Association for the Study of Obesity (EASO), in the presence of criteria for the exclusion of 
chronic diffuse liver disease of the viral, hereditary, autoimmune or drug genesis and according to the results of ultrasonographic research. The diagnosis of CHD was established according to the recommendations of the European Society of Cardiology Guidelines on the management of stable coronary artery disease.

The classification of obesity was conducted according to the body mass index (BMI): a ratio between weight to the squared height $\left(\mathrm{kg} / \mathrm{m}^{2}\right)$. According to BMI, general population is classified in five categories: underweight (BMI $<18.5 \mathrm{~kg} / \mathrm{m}^{2}$ ), normal weight (BMI 18.5-24.9 kg/m²), overweight (BMI 25.0-29.9 kg/m $)$, obesity of $1^{\text {st }}$ degree (BMI $30.0-34.9 \mathrm{~kg} / \mathrm{m}^{2}$ ), obesity of $2^{\text {nd }}$ degree (BMI 35.0-39.9 $\left.\mathrm{kg} / \mathrm{m}^{2}\right)$, obesity of $3^{\text {rd }}$ degree $\left(B M I>40 \mathrm{~kg} / \mathrm{m}^{2}\right)$.

Serum CK18, adiponectin and leptin levels were determined by the immunoassay analysis using the TPS ELISA test system (IDL Biotech AB, Sweden), Adiponectin ELISA test system (Mediagnost GvbH, Germany) and Leptin ELISA KIT (Diagnostics Biochem Canada Inc, Ontario) on the STAT FAX 303/PLUS analyzer (AWARENESS TECHNOLOGY, INC., USA) on the base of laboratory of the Higher State Educational Institution of Ukraine „Bukovinian State Medical University“. Leptin resistance (LR) was determined by the formula: $\mathrm{LR}=$ leptin $(\mathrm{ng} / \mathrm{ml}) /$ triglycerides $(\mathrm{mmol} / \mathrm{L})$.

The statistical processing of the results of the study was carried out using parametric (t-criterion Student, Fisher's F-criterion) and non-parametric methods (Mann-Whitney U-criterion, Wilcoxon's T-criterion) of variation statistics. For statistic and graphical analysis of the obtained results, we used software packages of Statistica for Windows version 10.0 Pro (Stat Soft inc., USA), Microsoft Excel 2013 (Microsoft, USA).

\section{Results}

The study of the level of CK 18 showed a statistically significant increase of this indicator in all studied groups: in patients of group 1 this indicator was increased by 3.8 times $(\mathrm{p}<0.05)$, in group 2 by 3.91 times $(\mathrm{p}<0,05)$ in comparison with PHP, with a statistically significant difference between patients from groups 1 and 2 ( $>0.05$ ) (Table 1). Also, there was no statistically significant difference in the levels of CK18 between men and women in the studied groups ( $\mathrm{p}>0.05)$.

In addition, it was found that in patients with obesity of the $2^{\text {nd }}$ degree, the content of CK18 was significantly higher $(\mathrm{p}<0.05)$ than in patients with obesity of the 1st degree, and didn't depend of the sex. Thus, in patients with obesity of the $1^{\text {st }}$ degree, the level of the CK 18 was 3.7 times higher than in the PHP $(p<0.05)(n=36)$, with obesity of $2^{\text {nd }}$ degree by 4,1 times higher than in the PHP $(p<0,05)(n=24)$, with statistically significant intergroup difference $(\mathrm{p}<0.05)$.

The study did not show a statistically significant increase of CK 18 level in patients with NASH with the increasing of the stage of liver fibrosis (LF), there was only a tendency to its increase with the increase of LF stage ( $>0.05)$. At the same time, the levels of CK 18 in patients with the LF of stage F0 amounted 398.2 $\pm 3.7 \mathrm{U} / \mathrm{L}, \mathrm{F} 1405.6 \pm 3.81 \mathrm{U} / \mathrm{L}$ and F2-F3 411.3 $\pm 4.1 \mathrm{U} / \mathrm{L}$, without statistically significant intergroup difference $(\mathrm{p}>0.05)$.

In the examined patients, a direct correlation was established between the level of CK 18 in serum and BMI $(r=0.69, p<0.05)$, cholesterol $(r=0.72$, $\mathrm{p}<0.05)$, low-density lipoproteins $(\mathrm{r}=0.41, \mathrm{p}<0.05)$, index HOMA2-IR $(r=0.58, p<0.05)$, glycosylated hemoglobin $(r=0.64, p<0.05)$, ALT $(r=0.75, p<0.05)$, AST $(r=0.69, p<0.05)$, GGTP $(r=0.57, p<0.05)$, and the inverse correlation with high-density lipoproteins content $(r=-0.25, p<0.05)$.

The study of the content of leptin in the blood serum of the examined patients showed a statistically significant increase of this adipocytokine in the examined groups: in group 1 this parameter was increased by 3.3 times $(\mathrm{p}<0.05)$ in comparison with PHP, in

Table 1. Levels of cytokeratin 18, adiponectin and leptin in patients with NASH and comorbid CHD.

\begin{tabular}{cccc}
\hline Indicator & $\begin{array}{c}\text { PHP } \\
(n=20)\end{array}$ & $\begin{array}{c}\text { NASH } \\
(n=30)\end{array}$ & NASH + CHD $(n=30)$ \\
\hline Cytokeratin $18, \mathrm{U} / 1$ & $104,8 \pm 3,52$ & $397,9 \pm 4,1^{*}$ & $410,4 \pm 3,9^{*}$ \\
\hline Adiponectin, $\mu \mathrm{g} / \mathrm{ml}$ & $10,58 \pm 0,15$ & $6,34 \pm 0,08^{*}$ & $5,46 \pm 0,09^{*} /^{* *}$ \\
\hline Leptin, $\mathrm{ng} / \mathrm{ml}$ & $6,13 \pm 0,5$ & $20,28 \pm 1,01^{*}$ & $28,65 \pm 1,03^{*} *^{* *}$ \\
\hline Leptin resistance, units & $3,8 \pm 0,05$ & $7,14 \pm 0,06^{*}$ & $9,07 \pm 0,08^{* * *}$ \\
\hline
\end{tabular}

Notes: * - the difference is statistically significant in comparation with the same indicator in practically healthy persons $(\mathrm{p}<0,05) ;{ }^{* *}$ - the difference is statistically significant in comparison with the indicator in patients with NASH $(\mathrm{p}<0,05)$. $\mathrm{CHD}=$ coronary heart disease

$\mathrm{NASH}=$ non-alcoholic steatohepatitis

$\mathrm{PHP}=$ practically healthy persons. 
group 2 - by 4.7 times $(p<0.05)$ in comparison with PHP, with a statistically significant intergroup difference $(p<0.05)$ (Table 1). In addition, in both groups, a higher level of leptin was found in women: in group 1 - by $11 \%$ (in women $21.46 \pm 1.02 \mathrm{ng} / \mathrm{mL}(\mathrm{p}<0.05)$ $(\mathrm{n}=14)$, in men $19.1 \pm 0.09 \mathrm{ng} / \mathrm{mL}(\mathrm{p}<0.05)(\mathrm{n}=16))$, in group 2 - by $15.3 \%$ (in women $30.7 \pm 1.02 \mathrm{ng} / \mathrm{mL}$ $(\mathrm{p}<0,05)(\mathrm{n}=15)$, in men $26.6 \pm 1.01 \mathrm{ng} / \mathrm{mL}(\mathrm{p}<0.05)$ $(n=15))$. It was also found that the content of leptin was higher in patients with $2^{\text {nd }}$ degree obesity than in patients with $1^{\text {st }}$ degree obesity. Thus, in patients with $1^{\text {st }}$ degree obesity, the level of leptin was $20.57 \pm 0.08$ $\mathrm{ng} / \mathrm{mL}(\mathrm{p}<0.05)(\mathrm{n}=36)$, in those with $2^{\text {nd }}$ degree obesity $27.36 \pm 1.02 \mathrm{ng} / \mathrm{mL}(\mathrm{p}<0.05)(\mathrm{n}=24)$.

The indicator of LR showed the following changes: in the group 1, this indicator exceeded by 1.23 times $(\mathrm{p}<0.05)$ that in PHP, in group 2 by 1.56 times $(p<0.05)$. The rate of LR in women was significantly higher than in men: in group $1-7.37 \pm 0.07$ units $(\mathrm{p}<0.05)(\mathrm{n}=14)$ in women and $6.91 \pm 0,06$ units $(\mathrm{p}<0.05)(\mathrm{n}=16)$ in men, in group $2-9.25 \pm 0.08$ units $(\mathrm{p}<0.05)(\mathrm{n}=15)$ in women and $8.89 \pm 0.06$ units $(p<0.05)(n=15)$ in men. The rate of LR was significantly higher in persons with the $2^{\text {nd }}$ degree obesity: in patients with 1st degree obesity, this indicator was $7.21 \pm 0.05$ units $(\mathrm{p}<0.05)(\mathrm{n}=36)$, with $2^{\text {nd }}$ degree obesity $-8.49 \pm 0.06$ units $(\mathrm{p}<0.05)$ $(\mathrm{n}=24)$.

We found a direct correlation between the level of leptin and BMI $(\mathrm{r}=0.59 ; \mathrm{p}<0.05)$, waist circumference $(r=0.52 ; p<0.05)$, the content of cholesterol $(\mathrm{r}=0.41, \mathrm{p}<0.05), \mathrm{TG}(\mathrm{r}=0.35 ; \mathrm{p}<0.05)$, the inverse correlation with high-density lipoproteins content $(\mathrm{r}$ $=-0.45 ; \mathrm{p}<0.05$ ).

The study of the level of adiponectin showed a statistically significant decrease of this indicator in patients with NASH: in group 1, adiponectin level was by 1.67 times $(p<0.05)$ lower compared with PHP, in group 2 - lower by 1.94 times $(\mathrm{p}<0.05)$, with a statistically significant intergroup difference $(p<0.05)$. At the same time, in patients with the obesity of 2 nd degree, this indicator was lower in comparison with patients with the obesity of Ist degree: in patients with obesity of Ist degree, this indicator was $6.32 \pm 0.06 \mu \mathrm{g} / \mathrm{mL}(\mathrm{p}<0.05)$, with obesity of IInd degree $-5.49 \pm 0.07 \mu \mathrm{g} / \mathrm{mL}(\mathrm{p}<0.05)$. There was no statistically significant difference between adiponectin content in blood serum between men and women $(p>0.05)$. We found a negative correlation between the level of adiponectin and BMI $(r=-0.41, p<0.05)$, body weight $(r=-0.45, p<0.05)$, waist circumference $(r=-0.49, p<0.05)$, HOMA-IR $(r=-0.39, p<0.05)$, positive - with the level of high-density lipoproteins content $(\mathrm{r}=0.44, \mathrm{p}<0.05)$.

\section{Discussion}

The detected elevated levels of CK 18 indicate an increased loss of liver cells, which may lead to the progression of NASH, the LF's development and its subsequent transformation into liver cirrhosis. Our data and literature data, ${ }^{7,10-14}$ confirm that uncontrolled hepatocyte apoptosis can be the central mechanism that causes fibrogenesis and LF. In the majority of the examined patients, the degree of fibrosis according to the liver ultrasound elastography was F0-F1 ( $\mathrm{n}=54)$, a small number of patients had F2-F3 degrees of fibrosis $(n=6)$. There was no correlation between the degree of LF and the level of CK 18, there was only a tendency to increase the content of CK 18 with an increase of the degree of LF. This may indicate a parallelism between the hepatocyte apoptosis and the inflammatory-fibrotic process in the liver of patients with NASH.

The positive correlation between the activity of ALT and the content of CK 18 indicates the activation of inter-parallel and interrelated processes of damage and loss of parenchymal liver tissue in $\mathrm{NASH}$, through necrosis and apoptosis of hepatocytes. In addition, in the examined patients with $\mathrm{NASH}$, there were signs of intrahepatic cholestasis, manifested by an increase of enzymes GGT and alkaline phosphatase (AF). As a result of cholestasis in hepatocytes, delayed hydrophobic bile acids, which have toxic effects on cells, cause the development of oxidative stress, the expression of pro apoptotic transcription factors, the activation of the internal and external ways of apoptosis 8 ,10-12,14.

CK 18 in the examined patients was closely correlated only with the level of cholesterol $(\mathrm{r}=0.72$, $\mathrm{p}<0.05)$. Such a strong correlation between the level of cholesterol and the CK 18, as a marker of the hepatocyte apoptosis, is due to the fact that cholesterol accumulates in cells and causes mitochondrial dysfunction, it increases the synthesis of active forms of oxygen, enhances the development of endoplasmic stress and apoptosis and leads to the progression of the disease ${ }^{10-12,15,16}$.

High levels of leptin in the examined groups of patients with obesity is due to leptin resistance (LR). Because of LR, the formation of TG is increased and lipid peroxide oxidation is activated, which may lead to the development of lipo-toxicity and, as a consequence, to metabolic disorders ${ }^{4,5,17-20}$. A higher concentration of leptin in patients with a comorbid $\mathrm{NASH}$ and $\mathrm{CHD}$ is due to more profound disorders of lipid and carbohydrate metabolism, decompensated oxidative stress in patients with concomitant $\mathrm{CHD}^{21-22}$. This fact suggests that $\mathrm{CHD}$ worsens the course and prognosis of patients with $\mathrm{NASH}^{18,20}$. 
Reduced adiponectin levels in the examined patients is an unfavorable predictor of the development and progression of NASH with comorbid $\mathrm{CHD}$, because of the fact that this cytokine has a number of protective functions that are important for this comorbidity: anti-inflammatory, antidiabetic, angio-protective and cardioprotective ${ }^{18}$. A higher reduction of the adiponectin level in the group of patients with NASH and comorbid CHD and obesity of $1^{\text {st }} 2^{\text {nd }}$ degree indicates that the low level of this cytokine is a predictor of progression of CHD. Hypoadiponectinemia in patients with $\mathrm{NASH}$ and obesity contributes to the development of cardiovascular complications in this group of patients, as the adiponectin has a protective effect on the heart, it protects it from ischemic damages due to impaired blood circulation, through activation of ATP and cyclooxygenase $e^{17,18,23-25}$.

\section{Conclusions}

$\mathrm{NASH}$ is closely associated with disorders of adipocytokine homeostasis. In patients with $\mathrm{NASH}$, comorbid CHD, and obesity of $1^{\text {st }-2^{\text {nd }}}$ degree, there is an increased level of CK 18, proinflammatory adipokine leptin and a decrease in the level of adiponectin. The significant increase of liver aminotransferase activity and the level of CK 18 fragment in patients with NASH, their close positive relationship suggest that the leading pathophysiological mechanism of progression of NAFLD is the necrosis and apoptosis of hepatocytes. The determination of serum fragments of CK 18 can be used as a non-invasive test for the diagnosis of $\mathrm{NASH}$ and liver steatosis.

\section{Compliance with Ethics Requirements:}

"The authors declare no conflict of interest regarding this article"

„The authors declare that all the procedures and experiments of this study respect the ethical standards in the Helsinki Declaration of 1975, as revised in 2008(5), as well as the national law."

"No funding for this study“

\section{References}

1. Machado MV, Cortez-Pinto H. Non-invasive diagnosis of non-alcoholic fatty liver disease. A critical appraisal. J Hepatol. 2013;58:1007-109.

2. Musso G, Gambino R, Cassader M. Non-alcoholic fatty liver disease from pathogenesis to management: an update. Obesity Reviews. 2010;11(6):430-445.
3. Bocsan IC, Milaciu MV, Pop RM, et al. Cytokines genotype-phenotype correlation in nonalcoholic steatohepatitis. Oxid Med Cell Longev. 2017;2017:4297206.

4. Fitzpatrick E, Dhawan A. Noninvasive biomarkers in non-alcoholic fatty liver disease: current status and a glimpse of the future. World J Gastroenterol. 2014;20(31):10851-10863.

5. Shen J, Chan H L-Y, Wong G L-H, et al. Non-invasive diagnosis of nonalcoholic steatohepatitis by combined serum biomarkers. J Hepatol. 2012;56:1363-1370.

6. Sumida Y, Nakajima A, Itoh Y. Limitations of liver biopsy and non-invasive diagnostic tests for the diagnosis of nonalcoholic fatty liver disease/nonalcoholic steatohepatitis. World J Gastroenterol. 2014;20(2):475-485.

7. Cusi K, Chang Z, Harrison S, et al. Limited value of plasma cytokeratin-18 as a biomarker for NASH and fibrosis in patients with non-alcoholic fatty liver disease. J Hepatol. 2014;60:167-174.

8. Feldstein AE, Wieckowska A, Lopez AR, Liu YC, Zein NN, McCullough AJ. Cytokeratin-18 fragment levels as noninvasive biomarkers for nonalcoholic steatohepatitis: a multicenter validation study. Hepatology. 2009;50(4):1072-1078.

9. Maher MM, Ibrahim WA, Saleh SA, et al. Cytokeratin 18 as a non-invasive marker in diagnosis of NASH and its usefulness in correlation with disease severity in Egyptian patients. The Egyptian Journal of Medical Human Genetics. 2015;16:41-46.

10. Shipovskaya AA, Kurbatova IV, Dudanova OP. The use of cytokeratin-18 fragments in diagnostics of non-alcohol fatty liver disease. Klinicheskaya meditsina. 2017; 95(10): 923-27.

11. Dudanova OP, Shipovskaya AA, Kurbatova IV. Apoptosis of hepatocytes in the early form of non-alcoholic fatty liver disease. Eksperimentalnaya i klinicheskaya gastroenterologiya. 2018;157(9):81-85.

12. Wang K. Molecular mechanisms of hepatic apoptosis. Cell Death Dis. 2014;5 (1): e996.

13. Vuppalanchi R, Deppe RB, Yates KP, et al. Changes in serum cytokeratin 18 levels significantly predict changes in liver histology in adults with nonalcoholic steatohepatitis: results from the Pivens trial. Gasteroentrology. 2013;144:951p.

14. Wu G, Li H, Fang Q, Zhang J, et al. Complementary role of fibroblast growth factor 21 and cytokeratin 18 in monitoring the different stages of nonalcoholic fatty liver disease. Sci Rep. 2017;7(1): 5095p.

15. Ioannou GN. The role of cholesterol in the pathogenesis of NASH. Trends Endocrinol Metab. 2016;27(2):84-95.

16. Miyasato M, Murase-Mishiba Y, Bessho M, et al. The cytokeratin-18 fragment level as a biomarker of nonalcoholic fatty liver disease in patients with type 2 diabetes mellitus. Clin Chim Acta. 2014;10:184-189.

17. Niederreiter L, Tilg H. Cytokines and fatty liver diseases. Liver Research. 2018;2(1):14-20.

18. Postoeva AV, Dvoryashina I. The role of insulin, leptin, adiponectin in forming of structural and functional changes of myocardium in obesity and their dynamics in weight loss. Ozhirenie i metabolizm. 2015;12(2):10-13.

19. Polyzos SA, Aronis KN, Kountouras J, et al. Circulating leptin in non-alcoholic fatty liver disease: a systematic review and meta-analysis. Diabetologia. 2016;59(1):30-43.

20. Polyzos SA, Kountouras J, Mantzoros CS. Leptin in nonalcoholic fatty liver disease: a narrative review. Metabolism. 2015;64(1):60-78.

21. Draghici T, Negreanu L, Bratu OG, et al. Liver abnormalities in patients with heart failure. Arch Balk Med Union. 2018;53(1):76-81. 
22. Yeung AWK, Tzvetkov N, El-Tawil OS, Bungau SG, Abdel-Daim MM, Atanasov AG. Antioxidants: scientific literature landscape analysis. Oxidative Medicine and Cellular Longevity 2019;2019:1-11, ID 8278454.

23. Finelli C, Tarantino G. What is the role of adiponectin in obesity related non-alcoholic fatty liver disease? World J Gastroenterol 2013; 19(6): 802-812.
24. Stojsavljević S, Gomerčić Palčić M, Virović Jukić L, et al. Adipokines and proinflammatory cytokines, the key mediators in the pathogenesis of non-alcoholic fatty liver disease. World J Gastroenterol. 2014; 20: 18070-18091.

25. Gatselis NK, Ntaios G, Makaritsis K, Dalekos GN. Adiponectin: a key playmaker adipocytokine in non-alcoholic fatty liver disease. Clin Exp Med. 2014; 14: 121-131. 